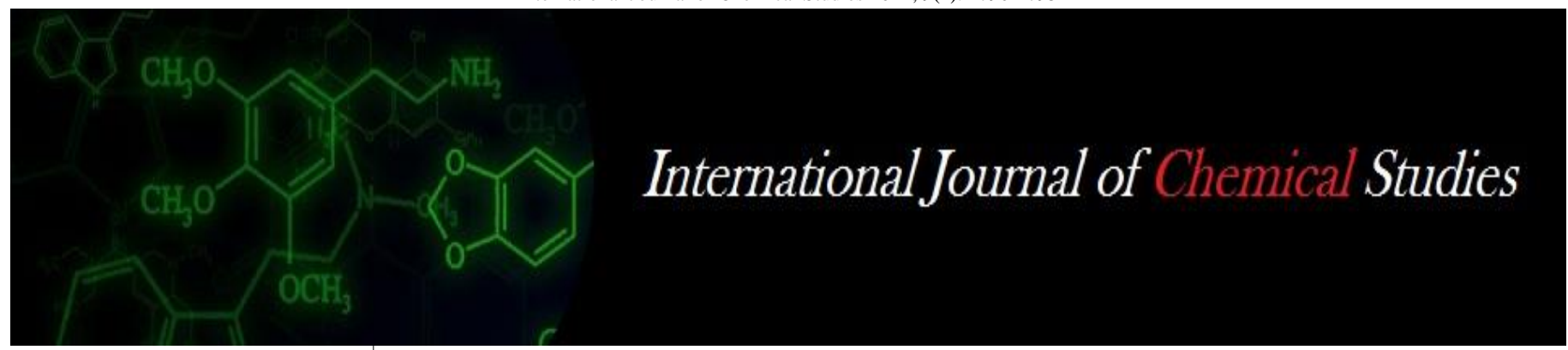

P-ISSN: 2349-8528

E-ISSN: 2321-4902

www.chemijournal.com

IJCS 2021; 9(1): 2790-2795

(C) 2021 IJCS

Received: 06-10-2020

Accepted: 14-12-2020

Yashaswini JP,

Department of Food

Engineering, Indian Institute of

Food Processing Technology,

Thanjavur, Tamil Nadu, India

N Venkatachalapathy

Department of Food

Engineering, Indian Institute of

Food Processing Technology,

Thanjavur, Tamil Nadu, India

Kulbhushan Sharma

Department of Food

Engineering, Indian Institute of

Food Processing Technology,

Thanjavur, Tamil Nadu, India

\section{R Jaganmohan}

Department of Food Product Development, Indian Institute of Food Processing Technology,

Thanjavur, Tamil Nadu, India

Akash Pare

Department of Academics and

Human Resource Development,

Indian Institute of Food

Processing Technology,

Thanjavur, Tamil Nadu, India

Corresponding Author:

N Venkatachalapathy

Department of Food

Engineering, Indian Institute of

Food Processing Technology,

Thanjavur, Tamil Nadu, India

\section{Effect of microwave vacuum drying on nutritional composition of moringa (Moringa oleifera) leaves}

\author{
Yashaswini JP, N Venkatachalapathy, Kulbhushan Sharma, R \\ Jaganmohan and Akash Pare
}

DOI: $\underline{\text { https://doi.org/10.22271/chemi.2021.v9.i1am.11648 }}$

\begin{abstract}
Moringa (Moringa Oleifera) is well known for its medicinal and functional food properties. Microwave vacuum drying is an assisted drying technology that aims to preserve the nutrients and improve overall product quality. In this study, different microwave power levels and vacuum on the nutrients and phytochemical constituents were investigated. Moringa leaves were procured and subjected to microwave vacuum drying at three different microwave power levels $(90 \mathrm{~W}, 270 \mathrm{~W}$ and $450 \mathrm{~W}$ ) at $500 \mathrm{~mm} \mathrm{Hg}$ vacuum pressure. The nutrients of the leaves were determined using standard analytical methods. Data were analysed and interpreted using one-way ANOVA. There was no significant difference in the moisture and fat content between the dried samples. Crude fibre content tends to decrease with the increase in power level, whereas protein and total carbohydrate content tend to increase with the power level. Highest TPC and DPPH radical scavenging activity were reported at $450 \mathrm{~W}$ microwave power level. The total colour difference, i.e., was least in the sample dried at $450 \mathrm{~W}$ and high for samples dried at $90 \mathrm{~W}$.
\end{abstract}

Keywords: Microwave, drying, nutritional, moringa, Moringa oleifera

\section{Introduction}

Moringa Oleifera belongs to the family moringaceae, and it is considered an extensively cultivated species of monogeneric family around the globe. Moringa Oleifera is native to the Indian subcontinent and is widely acclimated in tropical and subtropical regions, namely Africa, Asia, and South America (Mughal, Ali et al., 1999) ${ }^{[13]}$ and (Somali, Bajneid 1984) ${ }^{[27]}$. Several synonyms also know moringa tree as 'The Spinach Tree,' 'Horse Radish Tree,' 'Drumstick Tree,' 'West Indian Ben,' (Ramachandran et al., 1980) ${ }^{[22]}$, and in India, it goes by different names such as' Murungai," sahjan' or 'sohanjana' (Richter et al., 2003) ${ }^{[23]}$. Moringa Oleifera is labelled as the "miracle tree." It is a multipurpose and exceptionally nutritious vegetable tree with abundant potential uses. All parts of the tree, namely pod, fruit, leaves, are edible and a great nutrition source for all age groups. Moringa Oleifera leaves are considered to be a storehouse of rich nutritive compounds. It is a great source of digestible proteins, vitamins, minerals, and carbohydrates necessary for growth. The leaves are also free of antinutritive factors such as tannins and saponins (Fahey, 2005) ${ }^{[8]}$. Vitamin A and C, essential amino acids such as methionine, tryptophan, and lysine, are abundantly present in Moringa Oleifera leaves also consists of phytochemicals responsible for the antioxidant function. They also contain kaempferol and isoquercitrin as flavonoids.

The shelf life of fresh leaves (Moringa Oleifera) is a very short duration, approximately 2 to 3 days. Drying ensures reduction of water activity and improves the keeping quality of the leaves compared to the fresh leaves. The micro-nutrient content is even more in dried leaves in comparison with the fresh leaves. Common drying techniques employed for drying of $M$. Oleifera leaves include sun-drying and tray drying. Prolonged drying time, contamination of the product, loss of product quality accompanied by loss of nutritional value are some of the disadvantages involved when leaves are dried using conventional methods. The micro-nutrient content is even more in dried leaves (Mishra et al., 2012) ${ }^{[12]}$. Microwave drying can be employed to dry $M$. Oleifera leaves, higher thermal conductivity, precise control of the system, and energy-saving operations ensure that microwave drying has the upper hand in drying $M$. Oleifera leaves when compared to conventional methods (Potisate \& Phoungchandang, 2015) [19]. 
However, a rapid mass transfer would result in textural damage in some cases. Also, hot spots are formed due to the electric field's non-uniform distribution (Hu et al., 2006) ${ }^{[10]}$. To combat microwave drying limitation, microwave-assisted vacuum drying has been employed for drying fruits and vegetables. This method of drying rate of mass transfer is increased by increasing the pressure gradient between inner and outer layers and carrying out the drying process at low temperatures (Péré \& Rodier, 2002) ${ }^{[18]}$. In the present context, the microwave-vacuum drying method can be considered as a novel drying technique. It allows shorter drying time and a considerable improvement in the quality of dried materials (Bondaruk et al., 2007) ${ }^{[4]}$. Microwave Vacuum drying is a combination of drying Technology where the potential of microwave energy is combined with a vacuum environment for rapid, low-temperature dehydration. Limitations of conventional drying techniques such as hot air drying can be addressed using microwave vacuum drying. Dried moringa leaves have great market potential. The quality characteristics and retention of bioactive compounds in moringa leaves are solely dependent on drying methods. Microwave vacuum drying technique can be employed in the drying of moringa leaves for better product quality and resulting in higher retention of bioactive compounds. This study aims to examine the nutritional value and phytochemical constituents of methanol extracts and present in the microwave vacuum dried moringa leaf powder and also study the impact of microwave vacuum drying on the quality parameters such as colour and water activity which helps in describing the fact that better quality can be achieved using this drying technique.

\section{Material and Methods \\ Raw material}

Fresh moringa leaves were procured from the local market at Thanjavur, Tamil Nadu. Diseased and damaged leaves were discarded manually, then leaves were washed in running tap water until the dirt is completely removed. Later, the washed leaves were soaked in $0.1 \% \mathrm{NaCl}$ for 5 minutes to eliminate surficial microbes and leaves were further washed with distilled water. Excess water was removed by spreading leaves on a tray for a brief period (approximately $30 \mathrm{~min}$ ) at ambient temperature. The leaves were then packed airtight and stored in refrigerated conditions (approximately $4{ }^{\circ} \mathrm{C}$ ), which was used for further analysis.

\section{Experimental setup}

The experimental setup consisted of a domestic microwave oven (Model: IFB 30SC4) with a maximum magnetron output power of $0.9 \mathrm{~kW}$ of frequency-2450MHz, a glass vacuum desiccator, vacuum pump (Value double stage vacuum pump $(\mathrm{VE} 215 \mathrm{~N})$ ), hose pipe, vacuum gauge, pressure regulator, and air drying unit. The glass vacuum desiccator containing the sample was put inside the microwave, and this was attached to the vacuum pump through a hose pipe. The pressure regulator was used to control the vacuum pressure within the system, and the vacuum gauge indicated the vacuum pressure held up in the glass desiccator. The air drying unit consisted of a conical vacuum flask with silica gel. This unit entrapped the water vapour due to the drying of the product and ensured that it maintains the vacuum level. Moringa leaves were dried at three different microwave power levels $90 \mathrm{~W}, 270 \mathrm{~W}$ and $450 \mathrm{~W}$ microwave power level, and the drying system was maintained at a vacuum level of $500 \mathrm{~mm} \mathrm{Hg}$. The dried moringa leaves were powdered using a food processor, and then the powder is packed in LDPE plastic pouches and stored in a desiccator. The dried moringa leaf powder sample is analyzed to determine the physical parameters (colour and water activity) and chemical parameters (moisture content, crude protein, crude fibre, crude fat, total phenols, and antioxidant activity). The phenolic and antioxidant activity profiles are determined using chromatographic methods.

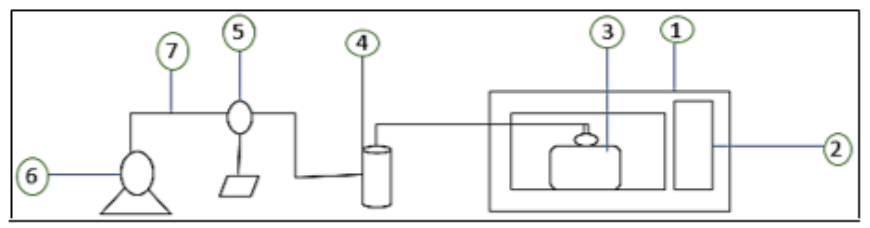

1. Microwave oven 2. Control panel 3. Glass vacuum desiccator

4. Air drying unit 5. Vacuum pressure gauge 6. Vacuum pump

7. Hose pipe and connections

Fig 1: Pictorial Representation of the Experimental setup colour

Hunter color lab flex meter (Make: Hunter Association Laboratory, Inc., USA) is used to determine the color of a dried moringa leaves powder. The $\mathrm{L}^{*}$ value, which is the lightness index scale ranges from 0 (black) to 100 (white), $\mathrm{a}^{*}$ value indicates red to green scale ( $+a$ to $-a)$, and $b^{*}$ value ranges from yellow to ( $+\mathrm{b}$ to $-\mathrm{b}) . \Delta \mathrm{E}$ is calculated as follows (Naik et al., 2020.)

$\Delta \mathrm{E}^{*}=\sqrt{\left(L-L^{*}\right)^{2}+\left(a-a^{*}\right)^{2}+\left(b-b^{*}\right)^{2}}$

where $L^{*}, a^{*}$ and $b^{*}$ are the colour parameters of the Fresh moringa leaf sample and $L, a$ and $b$ are the color parameters of dried moringa leaves powder.

\section{Water activity}

The Water activity $\left(a_{\mathrm{w}}\right)$ of the dried tomato slices are determined using the Aqua Lab Water Activity Meter (4TE). This works on the principle of focusing the infrared beam on a tiny mirror, which determines the accurate dew point temperature and then translated into water activity. Water activity can be measured by placing a sample in a disposable cup in the water activity meter, sealing the sample chamber lid over the sample, and waiting for vapour equilibrium.

\section{Proximate composition}

\section{Determination of moisture content}

The moisture content of the samples was determined using the AOAC method (2005) ${ }^{[1]}$. $5 \mathrm{~g}$ of the sample was then placed in a pre-weighed Petri dish and then placed in an oven to dry at $105{ }^{\circ} \mathrm{C}$ for five hours. The moisture dishes were cooled, and the final weight of the dish was noted.

moisture content $=\frac{\text { Initial weight of sample }(g)-\text { Final weight of sample }(g)}{\text { Initial weight of sample }(g)}$

\section{Determination of crude fat}

Crude fat was determined using the Soxhlet method (AOAC, 2005) ${ }^{[1]} 2 \mathrm{~g}$ of sample was weighed and wrapped in filter paper, kept in a thimble. Sample contained thimbles were kept in an oil flask then $80 \mathrm{ml}$ of hexane solvent was added. Then oil flasks were kept in Soxhlet apparatus for processing. After completion of evaporation of solvent extract, contained flasks were dried at $105^{\circ} \mathrm{C}$ for $30 \mathrm{~min}$. The final weight of the flask was noted. 
Fat content $(\%)=\frac{\text { weight of fat extracted }(g)}{\text { weight of sample }(g)} \times 100$

\section{Determination of ash content}

The ash content was determined using the method described in AOAC (1995). $3 \mathrm{~g}$ of the sample was weighed into a crucible in a muffle furnace and heated at $550{ }^{\circ} \mathrm{C}$ for six hours until it became greyish coloured ash. The crucible was removed from the muffle furnace with a tong's help and placed in a desiccator for allowing it to cool. After cooling, it was reweighed, and the difference obtained the weight of the ash.

$\%$ Ash content $=\frac{\text { weight of ash conent }(g)}{\text { weight of sample }(g)} \times 100$

\section{Determination of protein}

Protein was analyzed by the Kjeldahl method (AOAC, 2005)

[1]. $0.2 \mathrm{~g}$ of samples are weighed into the digestion tube, and $5 \mathrm{~g} \mathrm{Na}_{2} \mathrm{SO}_{4}, 1 \mathrm{~g}$ of $\mathrm{CuSO}_{4}$ and $10 \mathrm{ml}$ of Conc $\mathrm{H}_{2} \mathrm{SO}_{4}$ are weighed into the digestion tube. The tubes were kept for digestion for three $\mathrm{h}$. The digested tubes are further distilled with $40 \% \mathrm{NaOH}, 4 \%$ Boric acid. The distillate is collected in a conical flask and titrated against $0.1 \mathrm{~N} \mathrm{HCl}$ with mixed indicator. Titrated value is noted when the solution turns pink.

$\%$ Nitrogen content $=\frac{(T V-B V) \times N \times 14.007 \times 100}{\text { weight of sample }(g)}$

$\mathrm{TV}=$ Titrant volume of sample $(\mathrm{ml}), \mathrm{BV}=$ Titrant volume of blank (ml), $\mathrm{N}=$ Normality of $\mathrm{HCl}$

$$
\% \text { Protein content }=\% \text { nitrogen content } \times 6.25
$$

\section{Determination of crude fibre}

Crude Fibre content was determined by Weende's method (AOAC, 2005) ${ }^{[1]}$. $2 \mathrm{~g}$ of the sample was weighed into a beaker, and $200 \mathrm{ml}$ of $1.25 \% \mathrm{H}_{2} \mathrm{SO}_{4}$ was added, and the mixture was boiled for 30 minutes. The solution was filtered with whatman filter paper; Then the residue was transferred into a beaker, and $200 \mathrm{ml}$ of $1.25 \% \mathrm{NaOH}$ was added and boiled for 30 minutes, after which it was filtered and rinsed with distilled water. The residue was transferred into a crucible and placed in a hot air oven at $100{ }^{\circ} \mathrm{C}$ for eight hours to dry. Then the crucibles were removed and placed in a desiccator to cool before weighing. After weighing, the sample was incinerated, cooled in a desiccator, and reweighed.

\section{Determination of carbohydrate}

The carbohydrate content of the test sample was determined by estimation using the arithmetic difference method.

$\%$ CHO $=100-(\%$ fat $+\%$ ash $+\%$ fiber $+\%$ protein $)$

\section{Determination of energy content}

The energy values ( $\mathrm{kcal} / 100 \mathrm{~g}$ ) were determined by multiply the values of carbohydrates, lipids and protein by a factor of $3.75,9$ and 4, respectively, and taking the sum expressed in kilocalories (Castillo-Lopez et al., 2017) ${ }^{[15]}$.

\section{Preparation of Methanol extracts for phytochemical analysis.}

Homogenizer assisted extraction was carried out to extract the polyphenol compounds from Moringa Oleifera leaves. $10 \mathrm{ml}$ of methanol was added to one gram of dried sample, and extraction was carried out using an IKA (T18 ULTRA TURRAX) Homogenizer at 20,000 rpm for 3 minutes. The extracts were then centrifuged using REMI Centrifuge (C-24 Plus) at $10,000 \mathrm{rpm}$ for 15 minutes at four ${ }^{\circ} \mathrm{C}$. The extracts were subjected to concentration using a rotary evaporator. Later the methanol extracts were dried to total dryness, and $2 \mathrm{ml}$ of methanol was added for resuspension. The extract solution was stored in vials and refrigerated conditions for further analysis (Rocchetti et al., 2019) ${ }^{[25]}$.

\section{Determination of Total Phenolic Content}

The concentration of total phenolic content in the extracts was measured by UV spectrophotometer (SICAN 2301) based on colorimetric oxidation or reduction. Folin-Ciocalteau Reagent (FCR), an oxidizing agent, was used to estimate the phenolic compounds in the leaves' extracts. In a series of test tubes, 0.1 $\mathrm{mL}$ of the extract in methanol was taken, $0.9 \mathrm{~mL}$ of distilled water, mixed with $2 \mathrm{~mL}$ of FCR and $1 \mathrm{~mL}$ of sodium carbonate $(20 \% \mathrm{v} / \mathrm{v})$. The tubes were then allowed to stand in the dark at room temperature for one hour before the absorbance was read at wave-length set at $760 \mathrm{~nm}$ against a blank. A standard curve was prepared using Gallic acid monohydrate. Using the standard curve, the total phenolic compound content was calculated and expressed as Gallic acid equivalent (GAE) in $\mathrm{mg} / \mathrm{g}$ of extracts (Sreelatha \& Padma, 2009) ${ }^{[28]}$.

\section{Determination of DPPH radical scavenging activity}

The methanol leaf extracts' antioxidant activity was estimated by measuring the ability to scavenge 2,2_-diphenyl-1picrylhydrazyl stable radical (DPPH). The spectrophotometrical assay was carried out as described previously (Nouman et al., 2016) [15] with slight modifications. $0.5 \mathrm{~mL}$ solution of the extract was added to $0.004 \%$ DPPH solution in methanol. The contents were vortexed vigorously and allowed to stand in the dark at ambient temperature conditions for $60 \mathrm{~min}$. A blank solution of methanol and DPPH was also prepared but without the sample. After one-hour incubation in the dark, the samples' absorbance and blank were read at $517 \mathrm{~nm}$ using a spectrophotometer (SICAN 2301). The capability to scavenge the DPPH radical was calculated using the equation.

DPPH radical scavenging activity $=\frac{\text { Absorbance control }- \text { Absorbance sample }}{.}$ Absorbance control

Software MINITAB 17.1 was used to analyse the significance of the difference between the various treatment groups. Mean values were considered significantly different when $p<0.05$. All samples were run in triplicates. Analysis of variance (ANOVA) was calculated using the standard ANOVA (oneway) procedure.

\section{Results and Discussion Colour}

Lightness ( $\mathrm{L}^{*}$ value), greenness (- $\mathrm{a}^{*}$ value), and yellowness $\left(+b^{*}\right.$ value $)$ of fresh moringa leaves were $39.34 \pm 0.010$, $8.607 \pm 0.005$ and $19.18 \pm 0.017$, respectively. As depicted in Fig.2, the lightness and the moringa leaf powder's yellowness were significantly increased after subjecting to microwave vacuum drying. The degree of change in the color indices is attributed to the parameters such as drying time, drying temperature and oxygen level. Prolonged drying time and higher temperature could lead to the conversion of chlorophylls to pheophytins. This change occurs due to the 
replacement of magnesium compounds present in the chlorophyll by hydrogen molecules (Rudra et al., 2008) ${ }^{[26]}$. Slower degradation of chlorophyll occurs when subjected to a shorter drying process (Drouzas \& Schubert, 1996) ${ }^{[7]}$. (Bondaruk et al., 2007) ${ }^{[4]}$ reported that improvement of the color of potato cubes is found with decreasing pressure. The results obtained correlated with the microwave vacuum drying of mint leaves (Therdthai \& Zhou, 2009) ${ }^{[29]}$.

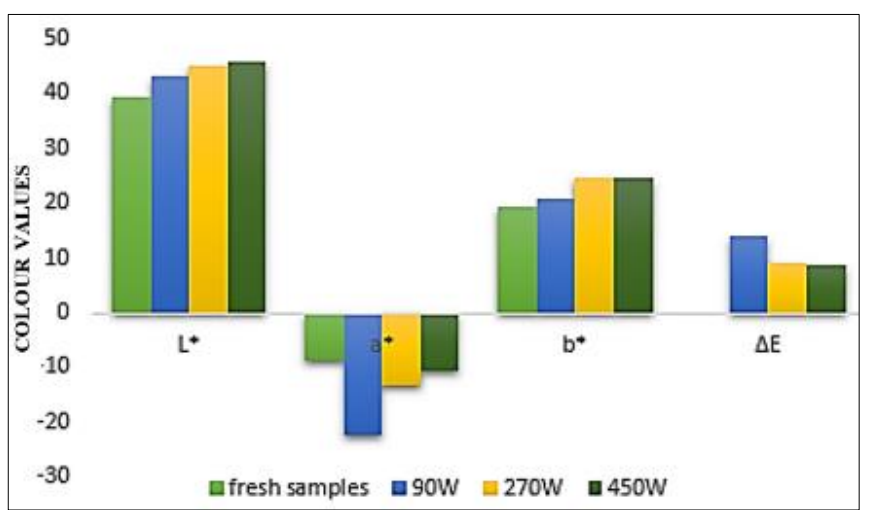

Fig 2: Colour degradation during microwave vacuum drying

\section{Water activity}

The water activity (aw) of the fresh sample and dried moringa oliefera leaf powder was 0.4171 to 0.4272 . There was no significant difference in the water activity level at varied microwave power levels presented in Table 1. As the moringa's water activity values were lower than 0.60 , they are considered safe and shelf-stable to microbial growth. (Rajkumar et al., 2007) ${ }^{[20] .}$

\section{Proximate composition}

The determination of dried moringa powder's proximate composition is crucial since it is an assessing factor to ascertain its nutritional significance. The chemical composition of microwave vacuum dried moringa leaves powder samples dried at varying power levels of microwave wattage to determine moisture content, ash content, crude protein, fat, total carbohydrates and crude fiber, which are presented in Table 1. Generally, the nutritional composition increased as the leaves were subjected to drying. This could be the result of an increase in the internal composition of nutrient as moisture is reduced (Foline et al., 2011) ${ }^{[9]}$.

\section{Moisture content}

The moisture content of the microwave vacuum dried moringa leaves powder ranged from $3.885 \pm 0.045 \%$ to $3.975 \pm 0.005 \%$. There was no significant difference $(p>0.05)$ in the moisture levels of the samples dried under varied microwave power levels (90 W to $450 \mathrm{~W}$ ). Rajput et al. (2017) [21] reported that fresh moringa leaves' moisture content was around 70-75 percent (w.b). Rigueiro-Rodríguez et al. (2002) ${ }^{[24]}$ reported that for herbs safe moisture content for successful preservation is less than 15 percent. Ali, Yusof, Chin, \& Ibrahim (2017) ${ }^{[2]}$ reported that microwave dried moringa leaves' moisture content is about $4.93 \%$ (w.b), the results obtained in the agreement of the reported value. Microwave vacuum drying involves greater moisture loss because of the rapid removal of water-bound within the food matrix, which is greatly influenced by the combination of both microwave power and vacuum conditions. The moisture content of microwave vacuum dried garlic slices was reduced to less than $5 \%$ (w.b) rapidly due to the microwave and vacuum's combined effect. (Wang et al., 2011) ${ }^{[30]}$.

\section{Crude fat}

Fat content ranged from $7.214 \pm 0.133 \%$ to $7.296 \pm 0.050 \%$. There was no significant difference between the crude fat level at varied microwave power levels $(p>0.05)$. The results obtained agreed to the crude fat content reported by (Isitua et al., 2015) ${ }^{[11]}$. Microwave drying may result in fat oxidation and fatty acid isomer formation (Bashir et al., 2020) ${ }^{[3]}$. Vacuum conditions in this particular study would influence the reported fat content (Pankyamma et al., 2019) ${ }^{[17]}$.

\section{Ash content}

The ash content ranged from $6.393 \pm 0.073 \%$ to $7.524 \pm 0.0878 \%$. There was a significant difference in ash contents $(p<0.05)$. The ash of the dried leaf powder is considered the measure of mineral content of the original food product. The ash content of the present study was in good agreement with the ash content reported by Isitua et al., (2015) ${ }^{[11]}$ around $11.5 \%$.

\section{Protein}

Dried moringa leaves could serve as a great protein source in human diets. There was a significant difference $(p<0.05)$ in the protein content between the samples dried at $90 \mathrm{~W}$ $(25.296 \pm 0.495)$ and samples dried at $450 \mathrm{~W}(31.230 \pm 0.883)$, there was no significant difference between the protein content of $270 \mathrm{~W}(28.816 \pm 0.0851)$ dried samples and $450 \mathrm{~W}$ $(31.230 \pm 0.883)$ dried samples in this particular study ( $p>$ 0.05). Ali et al. (2017) ${ }^{[2]}$ recorded $29 \%$ of crude protein in microwave dried moringa leaves. This result was close to the value obtained in the current study. The decrease in protein levels with decrease power levels and prolonged drying time may be attributed to a browning reaction involving loss of protein (Bashir et al., 2020) ${ }^{[3]}$.

\section{Crude fibre}

A significant difference $(p<0.05)$ in crude fibre level was observed among the samples. The highest fibre content was observed in samples dried at $90 \mathrm{~W}(15.228 \pm 0.238)$ and the lowest crude fibre content in samples dried at $450 \mathrm{~W}$ (11.926 \pm 0.189$)$. Olabode, Akanbi, Olunlade, \& Adeola (2015) ${ }^{[16]}$ reported that crude fibre content for oven-dried moringa leaves was around $17.56 \%$ to $17.26 \%$, the reported values in this study is in agreement with the value obtained in this particular study.

\section{Carbohydrates and Energy content}

The carbohydrate reported was highest in samples dried at 90 $\mathrm{W}(41.810 \pm 0.668)$ and lowest in samples dried at $450 \mathrm{~W}$ $(38.209 \pm 0.619)$, there was a significant difference $(p<0.05)$ in carbohydrate levels between the samples subjected drying at $90 \mathrm{~W}$ and $450 \mathrm{~W}$. There was no significant difference between the samples dried at $270 \mathrm{~W}(40.391 \pm 0.758)$ and $450 \mathrm{~W}$ (38.209 \pm 0.619$)$. Olabode et al. (2015) ${ }^{[16]}$ reported the carbohydrate to be around $45.55 \%$ to $35.99 \%$ for moringa leaves dried under varied oven temperatures. When subjected to high power levels, the decrease in carbohydrate content can be attributed to sugar's rapid caramelization at the higher temperature. When subjected to heating carbohydrates having less molecular weight is lost. The energy content ranged from $323.647 \pm 0.037 \mathrm{kcal} / \mathrm{kg}$ to $333.229 \pm 0.756 \mathrm{kcal} / \mathrm{kg}$. There was a significant difference in the energy content. The energy content of microwave dried moringa leaves was $380 \mathrm{kcal} / \mathrm{kg}$ 
(Ali et al., 2017) ${ }^{[2]}$. The results obtained in this particular study was close to the reported values.

\section{Total Phenol Content and DPPH Radical scavenging activity}

The antioxidant in plants is mainly due to the Total phenolic content since it acts as the main contributor to the antioxidant activity in herbs (Siti Mahirah et al., 2018) ${ }^{[26]}$. Total phenolic content (TPC) was determined from the calibration curves of Gallic acid. Antioxidant activity is reported in terms of DPPH radical scavenging activity. It was found that all the dried samples showed a significant increase in TPC, DPPH radical scavenging activity. TPC and antioxidant activity are reported higher in the sample dried at $450 \mathrm{~W}$ and $500 \mathrm{~mm} \mathrm{Hg}$ pressure.
The TPC content and DPPH radical scavenging activity $16.400 \pm 0.420 \mathrm{mg} / \mathrm{g}$ of dried leaves and $52.588 \pm 1.174 \%$, respectively. There is a significant difference between when a product is subjected to thermal processing, an increase in the total phenolic, and antioxidant activity because phytochemical bound within the food matrix is released. A possible synergistic effect with phytochemicals, such as phenolic and flavonoids, might be involved (Dewanto et al., 2002) ${ }^{[6]}$. A similar trend for an increase in Antioxidant activity and TPC content when moringa leaves were subjected to microwave drying at $900 \mathrm{~W}$ was reported by Potisate \& Phoungchandang, (2015) ${ }^{[19]}$. In this study, TPC content reported $14.28 \mathrm{mg} / \mathrm{g} \mathrm{d.1}$, and DPPH radical scavenging activity was around $46.33 \%$.

Table 1: Proximate composition, total phenolic content, radical scavenging activity and water activity

\begin{tabular}{|c|c|c|c|}
\hline Parameters & 90W & 270W & 450W \\
\hline Moisture (\%) & $3.975 \pm 0.005^{\mathrm{a}}$ & $3.905 \pm 0.035^{\mathrm{a}}$ & $3.885 \pm 0.045^{\mathrm{a}}$ \\
\hline Fat $(\%)$ & $7.225 \pm 0.017^{\mathrm{a}}$ & $7.214 \pm 0.133^{\mathrm{a}}$ & $7.296 \pm 0.050^{\mathrm{a}}$ \\
\hline $\operatorname{Ash}(\%)$ & $6.393 \pm 0.073^{\mathrm{c}}$ & $6.893 \pm 0.079^{\mathrm{b}}$ & $7.524 \pm 0.0878^{a}$ \\
\hline Crude protein $(\%)$ & $25.296 \pm 0.495^{\mathrm{c}}$ & $28.816 \pm 0.085^{\mathrm{b}, \mathrm{a}}$ & $31.230 \pm 0.883^{\mathrm{a}}$ \\
\hline Crude fibre $(\%)$ & $15.228 \pm 0.238^{\mathrm{a}}$ & $12.779 \pm 0.197^{\mathrm{b}}$ & $11.926 \pm 0.189^{\mathrm{c}}$ \\
\hline Total carbohydrate $(\%)$ & $41.810 \pm 0.668^{a}$ & $40.391 \pm 0.758^{\mathrm{b}, \mathrm{c}}$ & $38.209 \pm 0.619^{c}$ \\
\hline DPPH Radical scavenging activity (\%) & $40.536 \pm 0.946^{\mathrm{c}}$ & $46.412 \pm 1.028^{\mathrm{b}}$ & $52.588 \pm 1.174^{\mathrm{a}}$ \\
\hline Water activity $\left(\mathrm{a}_{\mathrm{w}}\right)$ & $0.4272 \pm 0.002^{\mathrm{a}}$ & $0.40755 \pm 0.04^{\mathrm{a}}$ & $0.4171 \pm 0.01^{\mathrm{a}}$ \\
\hline
\end{tabular}

*Values are triplicate and represent in Mean \pm SD; different superscripts in the same column mean that values are significantly different $(p<0.05)$

\section{Conclusion}

This study aimed to analyze the nutritional content and physical parameters of microwave vacuum dried moringa leaf powder dried using a lab-scale microwave vacuum drier at varied microwave power levels. The Total colour difference, i.e., $\Delta \mathrm{E}$, was lower for samples dried at $450 \mathrm{~W}$ microwave power. The water activity of the dried moringa leaves was reported to be below 0.6. there was no significant difference in moisture content and fat content in the samples dried at varying power levels. A significant difference in crude fibre content, ash content, TPC and DPPH radical scavenging activity was found between all the samples. There was no significant difference in crude protein, carbohydrate and the energy content between the samples dried at a $270 \mathrm{~W}$ and 450 $\mathrm{W}$ microwave power level. Microwave vacuum drying is an assisted technology that results in superior product quality with minimal loss in nutritional and phytochemical aspects.

\section{References}

1. AOAC. Association of Official Analytical Chemists 2005.

2. Ali MA, Yusof YA, Chin NL, Ibrahim MN. Processing of Moringa leaves as natural source of nutrients by optimization of drying and grinding mechanism. Journal of Food Process Engineering 2017;40(6):e12583.

3. Bashir N, Sood M, Bandral JD. Impact of different drying methods on proximate and mineral composition of oyster mushroom (Pleurotus florida). Indian Journal of Traditional Knowledge (IJTK) 2020;19(3):656-661.

4. Bondaruk J, Markowski M, Błaszczak WEffect of drying conditions on the quality of vacuum-microwave dried potato cubes. Journal of Food Engineering 2007;81(2):306-312.

5. Castillo-Lopez RI, Leon-Felix J, Angulo-Escalante MA, Gutierrez-Dorado R, Muy-Rangel MD, Heredia JB.
Nutritional and phenolic characterization of Moringa oleifera leaves grown in Sinaloa, Mexico. Pakistan Journal of Botany 2017;49(1):161-168.

6. Dewanto V, Wu X, Adom KK, Liu RH. Thermal processing enhances the nutritional value of tomatoes by increasing total antioxidant activity. Journal of Agricultural and Food Chemistry 2002;50(10):30103014.

7. Drouzas AE, Schubert H. Microwave application in vacuum drying of fruits. Journal of Food Engineering 1996;28(2):203-209.

8. Fahey JW. Moringa oleifera: a review of the medical evidence for its nutritional, therapeutic, and prophylactic properties. Part 1. Trees for Life Journal 2005;1(5):1-15.

9. Foline O, Emenike AF, Eunice BI. Comparative analysis of the nutritional composition of three different drying methods of Moringa oleifera leaves. International Journal of Applied Agricultural Research 2011;6:131-138.

10. Hu Q, Zhang M, Mujumdar AS, Xiao G, Jin-cai S. Drying of edamames by hot air and vacuum microwave combination. Journal of Food Engineering 2006;77(4):977-982.

11. Isitua CC, Lozano MJS, Jaramillo C, Dutan F. Phytochemical and nutritional properties of dried leaf powder of Moringa oleifera Lam. from machala el oro province of ecuador. Asian J. Plant Sci. Res 2015;5(2):816.

12. Mishra SP, Singh P, Singh S. Processing of Moringa oleifera leaves for human consumption. Bulletin of Environment, Pharmacology and Life Sciences 2012;2(1):28-31.

13. Mughal MH, Ali G, Srivastava PS, Iqbal $M$. Improvement of drumstick (Moringa pterygosperma Gaertn.)-a unique source of food and medicine through tissue culture. Hamdard Med 1999;42(1):37-42. 
14. Naik M, Natarajan V, Rawson A, Rangarajan J, Manickam L. (n.d.). Extraction kinetics and quality evaluation of oil extracted from bitter gourd (Momardica charantia L.) seeds using emergent technologies. LWT, 140:110714.

15. Nouman W, Anwar F, Gull T, Newton A, Rosa E, Domínguez-Perles R. Profiling of polyphenolics, nutrients and antioxidant potential of germplasm's leaves from seven cultivars of Moringa oleifera Lam. Industrial Crops and Products 2016;83:166-176. https://doi.org/10.1016/j.indcrop.2015.12.032

16. Olabode Z, Akanbi CT, Olunlade B, Adeola AA. Effects of drying temperature on the nutrients of Moringa (Moringa oleifera) leaves and sensory attributes of dried leaves infusion. Direct Research Journal of Agriculture and Food Science 2015;3(5):122-177.

17. Pankyamma V, Mokam SY, Debbarma J, Rao BM. Effects of microwave vacuum drying and conventional drying methods on the physicochemical and microstructural properties of squid shreds. Journal of the Science of Food and Agriculture 2019;99(13):57785783.

18. Péré C, Rodier E. Microwave vacuum drying of porous media: experimental study and qualitative considerations of internal transfers. Chemical Engineering and Processing: Process Intensification 2002;41(5):427-436.

19. Potisate Y, Phoungchandang S. Microwave Drying of Moringa oleifera (Lam.) Leaves: Drying Characteristics and Quality Aspects 2015;20(1):12-25.

20. Rajkumar P, Kulanthaisami S, Raghavan GSV, Gariépy Y, Orsat V. Drying kinetics of tomato slices in vacuum assisted solar and open sun drying methods. Drying Technology 2007;25(7-8):1349-1357.

21. Rajput H, Prasad SGM, Srivastav P, Singh N, Suraj L, Chandra R. Chemical and Phytochemical Properties of Fresh and Dried Moringa Oliferiea (PKM-1) Leaf Powder. Chemical Science Review and Letters 2017;6(22):1004-1009.

22. Ramachandran C, Peter KV, Gopalakrishnan PK. Drumstick (Moringa oleifera): a multipurpose Indian vegetable. Economic Botany 1980, 276-283.

23. Richter N, Siddhuraju P, Becker K. Evaluation of nutritional quality of moringa (Moringa oleifera Lam.) leaves as an alternative protein source for Nile tilapia (Oreochromis niloticus L.). Aquaculture 2003;217(14):599-611.

24. Rigueiro-Rodríguez A, López-Díaz ML, Iglesias-Rego R, Fernández-Núñez E, Fernández-Gómez S, Jardón-Bouzas $\mathrm{B}$ et al. Macronutrient content of the main natural herbs, shrubs and forage trees in NW Spain. Multi-Function Grasslands: Quality Forages, Animal Products and Landscapes. Proceedings of the 19th General Meeting of the European Grassland Federation, La Rochelle, France 2002, 90-91.

25. Rocchetti G, Blasi F, Montesano D, Ghisoni S, Marcotullio MC, Sabatini $\mathrm{S}$ et al. Impact of conventional/non-conventional extraction methods on the untargeted phenolic profile of Moringa oleifera leaves. Food Research International 2019;115:319-327.

26. Rudra SG, Sarkar BC, Shivhare US. Thermal degradation kinetics of chlorophyll in pureed coriander leaves. Food and Bioprocess Technology 2008;1(1):91-99.

Siti Mahirah Y, Rabeta MS, Antora RA. Effects of different drying methods on the proximate composition and antioxidant activities of Ocimum basilicum leaves. Food Research 2018;2(5):421-428.

27. Somali MA, Bajneid MA, Al- Fhaimani SS. Chemical composition and characteristics of Moringa peregrina seeds and seeds oil. Journal of the American Oil Chemists' Society 1984;61(1):85-86.

28. Sreelatha S, Padma PR. Antioxidant activity and total phenolic content of Moringa oleifera leaves in two stages of maturity. Plant Foods for Human Nutrition 2009;64(4):303-311. https://doi.org/10.1007/s11130-009-0141-0

29. Therdthai N, Zhou W. Characterization of microwave vacuum drying and hot air drying of mint leaves (Mentha cordifolia Opiz ex Fresen). Journal of Food Engineering 2009;91(3):482-489.

30. Wang J, Hu QH, Xin ZH. Study on the combined drying of microwave-vacuum drying (MVD) and air-drying (AD) of garlic slice. Sci. Technol. Food Industry 2011;32:280-283. 